\title{
Relationship between the three dimensions of institutes required for entrepreneurship development
}

Saurabh Sonkar ${ }^{1}$, Ashoke Kumar Sarkar ${ }^{2}$

School of Management Sciences, Central University of Jharkhand, Ranchi, India ${ }^{1,2}$ sonkarsaurabh23@gmail.com ${ }^{1 *}$, ashokecuj@gmail.com ${ }^{2}$

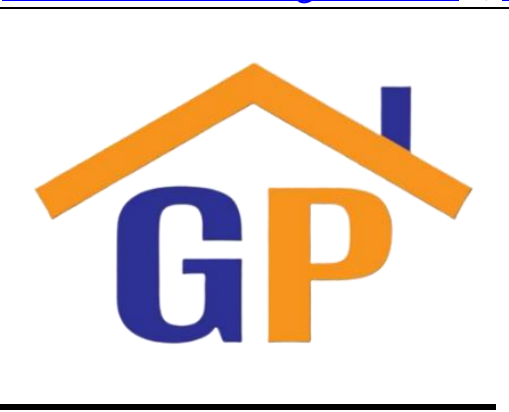

Article History

Received on 16 March 2021

Revised on 18 May 2021

Accepted on 25 May 2021

\begin{abstract}
Purpose: The study was conducted to formulate the relationship between the three dimensions of institutes, namely cognitive, regulative and, normative dimensions of institutes. The model was formulated using SmartPLS 3.
\end{abstract}

Research Methodology: In this study, the Five-point Likert scale was used and the data were collected from postgraduate students in two states of Uttar Pradesh and Jharkhand. SmartPLS 3 was used to formulate the model and establish the relationship between the three dimensions of institutes.

Results: There exists a positive relationship between "Cognitive dimension and normative dimension"; "Regulative dimensions and Cognitive dimensions; and between Regulative dimensions and Normative dimensions" respectively of institutes.

Limitations: Study is conducted on a small sample of 100 postgraduate students from two states of India namely Jharkhand and Uttar Pradesh which may decrease the reliability of the study.

Contribution: In this study, a relationship is established by using smart PLS 3 between the three dimensions of institutes required for entrepreneurship development with the help of Likert scale developed based on previous studies which can help in measuring the country institutional profile and provide the base for studying the role of these dimension of the institute in entrepreneurial intention growth among the postgraduate students in states of India.

Keywords: Regulative Dimensions, Normative Dimension, Cognitive Dimension, Entrepreneurship, Institutes

How to cite: Saurabh Sonkar., \& Sarkar, A. K. (2021) Relationship between the three dimensions of institutes required for entrepreneurship development. Journal of Sustainable Tourism and Entrepreneurship, 2(1), 53-68.

\section{Introduction}

"Entrepreneurship is a complex phenomenon that spans to a variety of contexts" (Jeraj, Mitja; Marič, 2013). It can be defined in three ways as given "Entrepreneurship can be if it conforms to legal requirements (regulatory dimension) if it is seen as legitimate through a common frame of reference (cognitive dimension) and if it conforms to the existent moral base (normative dimension)" (Petrovskaya, Zaverskiy, \& Kiseleva, 2017). On the other side, often the term "entrepreneur" is used for the creator of a new firm, or a person "who started a new business where was none before" (Duygulu, 2008). According to this definition, anybody who acquires purchases or, operates a business cannot be termed an entrepreneur. To fully utilize its potential many governments have attempted to encourage entrepreneurial activities (Zhai \& Su, 2019). In developing countries like India, entrepreneurship development becomes important as entrepreneurs help in the economic growth of the country by creating new business and providing jobs to others which increases productivity resulting in economic growth (Acs, 2006; Adenutsi, 2009; Baptista, Escária, \& Madruga, 
2008). Entrepreneurship development starts with the firm birth so it's become important to know who starts a new firm. And what are the driving factors which lead them to become entrepreneurs in place of working for others? (Reynolds,2013). Another important question is to find out the relations between these factors to understand the role of these factors on the development of entrepreneurship in any country.

An entrepreneur starts or runs an existing business in a business ecosystem that can act as a motivator as well as a hurdle in course of becoming a new entrepreneur. Institutions are an important part of the business ecosystem as they foster and identify the focused group's needs at a particular time. These institutes have three dimensions "normative, regulative and believes or cognitive". These three feasible dimensions of institute motivate the individual to opt for becoming an entrepreneur in place of working for others hence increases the likelihood of development of entrepreneurship ( Petrovskaya et al., 2017; Sine \& David, 2010; Urbano \& Alvarez, 2013).

The Country's institutional structure helps in understanding innovation emergence in the country by assessing the role of access to research and educational institutes in the country, access to the financial institutes for source financing, and access to human resources present in the country (SusanBartholome, 1997). The Entrepreneurial intention of an individual is an important factor to be understood to understand the new firm creation process (Arasti, Pasvishe, \& Motavaseli, 2012). Two dimensions of the institutional environment namely the normative dimension and regulative dimension show a decisive role in framing an intention towards entrepreneurship among Estonian university students (Wannamakok, Chang, \& Täks, 2020).

These three dimensions regulative, normative and cognitive have a relationship with entrepreneurial activity (Valdez \& Richardson, 2013). Regardless of the specific methods employed, one might consider the current literature to conclude that only the existence of favorable institutions leads to entrepreneurial intention. However, as (Valdez \& Richardson, 2013) points out that these three dimensions have significant conceptual overlapping in the institutional literature. Institutional elements - regulative, normative, cultural-cognitive - can not be harmonized and the effects of others can be undermined (Scott, Smith, \& Hitt, 2005). Apart from this overlapping the study conducted on "Chinese Academy of Sciences (CAS)' Knowledge Innovation Program (KIP)" highlights the relationship of cognitive and normative with regulative dimensions of institutions that focuses on boosting entrepreneurship (Daneil Erian Armanies;Charles E.Eesley, 2021). In the case of India, no study is present which establishes the relationship between the three dimensions of institutional profile for entrepreneurship development. So in this study, we have focused on developing the relationship between three dimensions of institutes present in India required for entrepreneurship development.

Using the samples of postgraduate students from Indian colleges and universities, we have tried to establish the relationship between three dimensions of institute responsible for building entrepreneurial intent among the postgraduate students in India. In this regard, we address three basic research questions in this study. The questions are 1. Is there a relationship between the regulative dimension and normative dimension of institute responsible for entrepreneurship development among postgraduate students in India, 2? Does the Regulative dimension has a relationship with the cognitive dimension of the institute responsible for entrepreneurship development among postgraduate students? And 3. Does the Cognitive dimension have any relationship with the normative dimension of institutes responsible for the development of entrepreneurship among postgraduate students in India? This study will be very first of its kind which we are aware of that is conducted based on primary data collected from postgraduate students using smart PLS 3 to establishing the relationship between the three-dimension responsible for the development of entrepreneurial intent among the student in turn responsible for entrepreneurship development in the country in the Indian context. 


\section{Literature review}

\subsection{Entrepreneurship}

Entrepreneurship is important because the level of entrepreneurship present in a country has a significant positive effect on the level of economic development of that particular country (Smith, $\underline{2010}$ ) as an enhanced economic performance by companies and regions will have a positive effect on aggregate national economic growth (Carree \& Thurik, 2010; J.Strom, 2007). Next important thing which entrepreneurship brings to the nation is job providing tool to youth (Bednarzik, 2000) that acts as a route out of poverty for all including disadvantage group also (Brown, 2013). In India entrepreneurship has created around 60000 direct jobs and around 1.3 to 1.6 lakhs indirect jobs in the financial year of 2019-20 (Dwivedi, 2021) that increases its importance further.

As in past studies, many approaches are adopted to study entrepreneurship development. One of them is an institutional approach that focuses on institutional theory. The institutional theory is directly or implicitly related to how communities and organizations can help ensure their status and authority by adhering to the norms and expectations of the institutional system (Bruton, Ahlstrom, \& Li, 2010). The institutional approach for entrepreneurship development is a relatively old concept in the international context of entrepreneurship development and research. It is found that little has been done on analyzing the previous studies conducted in India. For this role of institutes present in the state as well as central level becomes vital as they are regulated by central or state government respectively which shapes there environment in which entrepreneurs operates (Minniti, 2008). "A key role of the entrepreneurial environment is to help entrepreneurs develop both propensities to enterprise and ability to enterprise" (Nafukho \& Muyia, 2010). Flexible institutes are important for entrepreneurship development as they enhance individual entrepreneurial behavior in place of restricting their choices (Eesley, Roberts, Tian, \& Yang, 2014).

\subsection{Aspects of institution}

The normative, regulatory, and cognitive aspects of institutions shape the firm's environment, and if they are beneficial, they increase the likelihood of a person becoming an entrepreneur (Dickson \& Weaver, 2008). There are studies present around the globe regarding the impact of favorable dimensions on the development of entrepreneurship in different countries but hardly any study is present which establishes the relationship between three dimensions Regulative dimensions, Cognitive dimension and, Normative dimension of entrepreneurship.

\subsubsection{Normative dimension}

This dimension in the intuitional environment represents the norms and values present in the society and the constructs that enforce these norms and values in the society. These norms and values tend to define what is considered good or appropriate in turn these norms and values influence the entrepreneurial process and organizational forms (Sine \& David, 2010). It includes family context, believes and, society norms (Arasti et al., 2012). "Normative dimensions influence who will and who will not become an entrepreneur". According to (Lawrence \& Tolbert, 2007) career paths of individuals are influenced by the demographic factors at multiple levels including at the "individual level, on individuals' perceptions of work environments and career decisions, and at the organization level, on group dynamics and organizational selection processes". Influence on an organizational level is included in the normative factors for entrepreneurship as its influences entrepreneurship development in the country. Apart from this influence entrepreneurship development is also influenced by (Hayton, George, \& Zahra, 1979) by the culture of the country.

The normative dimension of the institutional environment represents the extent to which entrepreneurship development, innovative thinking and, value creation are admired in a country (Busenitz, Gómez, \& Spencer, 2000). In-country like India which has the second-largest population in the world normative factors gains much more importance than other countries. 


\subsubsection{Cognitive dimension}

Cognition is recognized as a different mode of entrepreneurship thinking as entrepreneurs think and imagine in different ways than non-entrepreneurs (Katz \& Shepherd, 2003). According to (Sánchez, Carballo, \& Gutiérrez, 2011) Cognitive approach of entrepreneurship help us to overcome the problems present in the traits approach and it focuses on the "Scripts, Self-efficiency, cognitive style, and heuristics" moreover according to (Stenholm, Acs, \& Wuebker, 2013) it represents the type of reality and cognitive framework through which individual drive useful information. Its influence and impact on society lie in the common arrangement or perception or solutions of given situations that are adopted and used by the individuals among them. Cognitive dimension represents awareness and expertise of the individual concerning the establishment of a new firm or running an existing firm present in any country becomes institutionalized and comes in the public domain for the use of all while in some countries probability of such happening is quite low as compared to others (Busenitz et al., 2000).

\subsubsection{Regulative dimension}

The regulative dimension deals with the formation of rules, regulations, and the process to implement the same correctly and appropriately along with imposing penalties on the people who don't follow or disobeys the rules and regulations formed over the period (Urbano \& Alvarez, 2013). Individuals and organizations tend to follow these rules and regulations in order not to get punished or suffer penalties from the government (Bruton \& Ahlstrom, 2003). Regulative factors including rules and regulation may encourage or discourage the individual to start a new firm as well as running the existing firm (Veciana \& Urbano, 2008).

\subsection{Hypotheses development}

A country having a large number of rules to be followed in its environment have less new business as many regulations discourage entrepreneurship development (Veciana \& Urbano, 2008). Along with it country having a free market, fewer regulations, and low entry barriers will have greater business opportunities hence will have more startups and firms (El-Namaki, 1988). All the formal and informal institutes present in a country have three dimensions namely the regulative dimension, normative dimension, and cognitive dimension. And these dimensions hold the key for the entrepreneurial development of any country and in turn help in boosting the economic development of the country as well as in states present inside the country.

(Baumol, 1990) According to him, institutes formulates structures of incentives hence helps in determining the entrepreneurial capacity of any country. (W.Richard Scott, 1995) They divided the entire institutional environment into three dimensions including the Regulative dimension; normative dimension and Cognitive Dimension and named them as institutional pillars so it's become important to formulate the relationship between these three important pillars required for entrepreneurship development in any country as well as in India.

These three dimensions evoke three distinct but connected credibility bases ( Veciana \& Urbano, 2008). All three dimensions including cognitive, normative, and regulative dimension have a relationship with entrepreneurial intention, entrepreneurial orientation, and entrepreneurial activity (Dickson \& Weaver, 2008; Spencer \& Gómez, 2003; Urban, 2019; Valdez \& Richardson, 2013). In the case of India, no study is present which establishes the relationship between the three dimensions of institution required for entrepreneurship development.

\subsubsection{Objective}

This study focuses on establishing the relationship between three dimensions of institutional environment responsible for entrepreneurship development among postgraduate students in India. 


\subsubsection{Research hypotheses}

* Hypothesis (H1) The regulative dimension of an institutional environment is positively related to the Cognitive dimension of an institutional environment.

* Hypothesis (H2) The cognitive dimension of an institutional environment is positively related to the normative dimension of an institutional environment.

* Hypothesis (H3) The regulative dimension of an institutional environment is positively related to the normative dimension of an institutional environment.

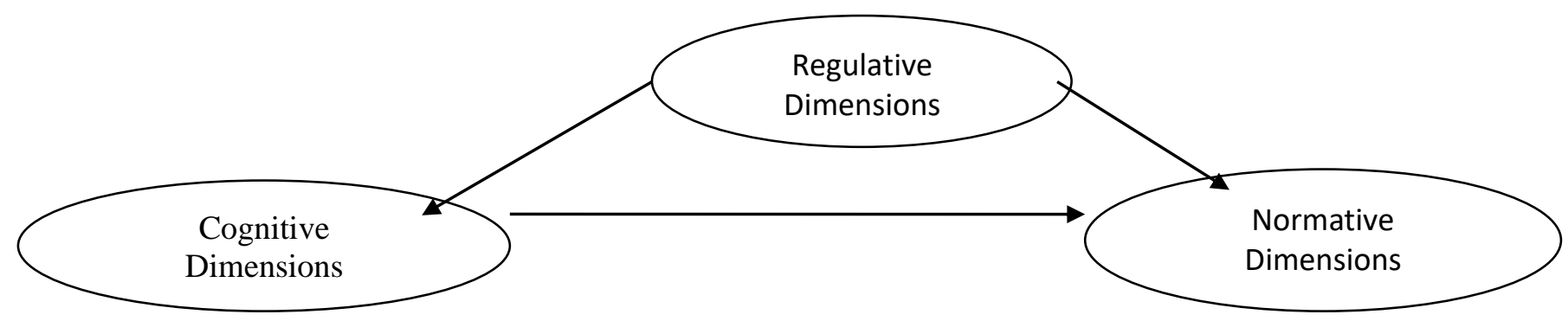

Figure 1. Proposed Model

\section{Research methodology}

This study questionnaire is formulated based on the previous studies conducted across the globe (Busenitz et al., 2000; Lim, Hoon, \& Clercq, 2015; Manolova, Eunni, \& Gyoshev, 2008; Urban, 2013). A questionnaire containing five-point Likert scales ranging from strongly disagree to strongly agree is developed and distributed online via Google doc's among the postgraduate student in two states of India namely Uttar Pradesh and Jharkhand. Out of 250 questionnaires sent only 109 Questioners are received back and 100 are used in the study. Data collected is analyzed by using Smart PLS 3 and SPSS 21. The questionnaire used in the study is given as follows

Table 1. Questionnaire

Five-point Likert Scale (1) "Strongly Disagree" (2) "Disagree" (3) "Neutral" (4) "Agree" (5) "Strongly Agree"

\begin{tabular}{|c|c|c|c|}
\hline \multicolumn{4}{|c|}{ Regulatory Dimension } \\
\hline Sr.no & Items & Questions & Source/Author \\
\hline 1 & $\mathrm{R} 1$ & $\begin{array}{l}\text { "Coping with government bureaucracy, } \\
\text { regulations, and licensing requirements it is } \\
\text { unduly difficult for new and growing firms" }\end{array}$ & ( Turulja et al., 2020) \\
\hline 2 & $\mathrm{R} 2$ & $\begin{array}{l}\text { "Taxes and other government regulation are } \\
\text { applied to new and growing firms predictably and } \\
\text { consistently" }\end{array}$ & (Turulja et al., 2020) \\
\hline 3 & R3 & $\begin{array}{l}\text { "The government sets aside government contracts } \\
\text { for new and small businesses" }\end{array}$ & $\underline{\text { (Gupta, Guo, \& }}$ \\
\hline 4 & R4 & $\begin{array}{l}\text { "Local and national governments have special } \\
\text { support available for individuals, who want to start } \\
\text { a new business", }\end{array}$ & (Busenitz et al., 2000) \\
\hline 5 & R5 & $\begin{array}{l}\text { "The government sponsors organizations that help } \\
\text { new businesses develop", }\end{array}$ & (Busenitz et al., 2000) \\
\hline 6 & R6 & $\begin{array}{l}\text { "Even after failing in an earlier business. The } \\
\text { government assists entrepreneurs in starting again" }\end{array}$ & (Busenitz et al., 2000) \\
\hline 7 & R7 & $\begin{array}{l}\text { "New firms can get most of the required permits } \\
\text { and licenses in about a week" }\end{array}$ & (Lim et al., 2015) \\
\hline 8 & $\mathrm{R} 8$ & $\begin{array}{l}\text { "The support for new and growing firms is a high } \\
\text { priority for policy at the local government level" }\end{array}$ & (Turulja et al., 2020) \\
\hline
\end{tabular}




\begin{tabular}{|c|c|c|c|}
\hline \multicolumn{4}{|c|}{ Cognitive Dimension } \\
\hline Sr.No & Items & Questions & Source/Author \\
\hline 1 & $\mathrm{C} 1$ & "Individuals know how to legally protect a new business", & (Busenitz et al., 2000) \\
\hline 2 & $\mathrm{C} 2$ & $\begin{array}{l}\text { "Those who start new businesses know how to deal with } \\
\text { many risks", }\end{array}$ & (Busenitz et al., 2000) \\
\hline 3 & $\mathrm{C} 3$ & $\begin{array}{l}\text { "Those who start new businesses know how to manage } \\
\text { risk", }\end{array}$ & (Busenitz et al., 2000) \\
\hline 4 & $\mathrm{C} 4$ & $\begin{array}{l}\text { "Most people know where to find information about } \\
\text { markets for their products", }\end{array}$ & (Busenitz et al., 2000) \\
\hline 5 & $\mathrm{C} 5$ & $\begin{array}{l}\text { "Colleges and universities provide good and adequate } \\
\text { preparation for starting up and growing new firms" }\end{array}$ & (Lim et al., 2015) \\
\hline 6 & C6 & $\begin{array}{l}\text { "The level of business and management education } \\
\text { provides good and adequate preparation for starting up } \\
\text { and growing new firms" }\end{array}$ & (Lim et al., 2015) \\
\hline 7 & $\mathrm{C7}$ & $\begin{array}{l}\text { "The vocational, professional, and continuing education } \\
\text { systems provide good and adequate preparation for } \\
\text { starting up and growing new firms" }\end{array}$ & (Lim et al., 2015) \\
\hline \multicolumn{4}{|c|}{ Normative Dimensions } \\
\hline Sr.No & Items & Questions & Author and Source \\
\hline 1 & $\mathrm{~N} 1$ & $\begin{array}{l}\text { "Turning new ideas into businesses is an admired career } \\
\text { path", }\end{array}$ & (Busenitz et al., 2000) \\
\hline 2 & $\mathrm{~N} 2$ & $\begin{array}{l}\text { "The creation of new ventures is considered an } \\
\text { appropriate way to become rich" }\end{array}$ & (Lim et al., 2015) \\
\hline 3 & N3 & "Entrepreneurs are admired in this country", & (Busenitz et al., 2000) \\
\hline 4 & N4 & $\begin{array}{l}\text { "Most people think of entrepreneurs as competent, } \\
\text { resourceful individuals" }\end{array}$ & (Lim et al., 2015) \\
\hline 5 & N5 & $\begin{array}{l}\text { "There are stories in the public media about successful } \\
\text { entrepreneurs" }\end{array}$ & (Lim et al., 2015) \\
\hline 6 & N6 & $\begin{array}{l}\text { "Successful entrepreneurs have a high level of status and } \\
\text { respect" }\end{array}$ & (Lim et al., 2015) \\
\hline
\end{tabular}

Table 2. Descriptive analysis

\begin{tabular}{cccccc}
\hline Questions & N & Minimum & Maximum & Mean & Std deviation \\
\hline R1 & 100 & 1 & 5 & 3.3300 & 1.10147 \\
R2 & 100 & 1 & 5 & 3.4800 & 1.14133 \\
R3 & 100 & 1 & 5 & 3.5200 & 1.05868 \\
R4 & 100 & 1 & 5 & 3.9000 & 1.07778 \\
R5 & 100 & 1 & 5 & 3.7900 & 1.06643 \\
R6 & 100 & 1 & 5 & 3.4700 & 1.14111 \\
R7 & 100 & 1 & 5 & 3.1500 & 1.24215 \\
R8 & 100 & 1 & 5 & 3.6000 & 1.17207 \\
C1 & 100 & 1 & 5 & 3.2600 & 1.07891 \\
C2 & 100 & 1 & 5 & 3.4700 & 1.17598 \\
C3 & 100 & 1 & 5 & 3.5000 & 1.25931 \\
C4 & 100 & 1 & 5 & 3.4300 & 1.14816 \\
C5 & 100 & 1 & 5 & 3.1400 & 1.27144 \\
C6 & 100 & 1 & 5 & 3.3500 & 1.20918 \\
C7 & 100 & 1 & 5 & 3.3800 & 1.18731 \\
N1 & 100 & 1 & 5 & 3.7100 & 1.09448 \\
N2 & 100 & 1 & 5 & 3.5200 & .96901 \\
N3 & 100 & 1 & 5 & 3.5500 & 1.05768 \\
N4 & 100 & 1 & 5 & 3.6300 & .99143 \\
N5 & 100 & 1 & 5 & 3.9900 & .95869 \\
N6 & 100 & 1 & 5 & 4.0300 & 1.05844 \\
\hline
\end{tabular}

2020 | Journal of Sustainable Tourism and Entrepreneurship/ Vol 2 No 1, 53-68 


\begin{tabular}{|c|c|c|c|c|}
\hline \multicolumn{5}{|l|}{$\begin{array}{l}\text { Valid N list } \\
\text { wise }\end{array}$} \\
\hline \multicolumn{5}{|c|}{$\begin{array}{l}\text { Table } 3,4 \text {, and } 5 \text { represent the ages, specialization of the respondent student, and the type of } \\
\text { institution to which the respondent belongs respectively. }\end{array}$} \\
\hline Table 3. Age & & & & \\
\hline Age Groups & Frequency & Percentage & Valid percent & $\begin{array}{l}\text { Cumulative } \\
\text { Percent }\end{array}$ \\
\hline 19 -22 years & 33 & 33.0 & 33.0 & 33.0 \\
\hline 23-26 years & 45 & 45.0 & 45.0 & 78.0 \\
\hline 27-30 years & 7 & 7.0 & 7.0 & 85.0 \\
\hline 30 above & 15 & 15.0 & 15.0 & 100 \\
\hline Total & 100 & 100.0 & 100.0 & \\
\hline
\end{tabular}

Table 4. Specialization

\begin{tabular}{lllcc}
\hline & Frequency & Percent & Valid percent & $\begin{array}{l}\text { Cumulative } \\
\text { percent }\end{array}$ \\
\hline $\begin{array}{l}\text { Management or } \\
\text { commerce }\end{array}$ & 68 & 68.00 & 68.00 & 68.00 \\
$\begin{array}{l}\text { Science or } \\
\text { Technology }\end{array}$ & 20 & 20.00 & 20.00 & 88.00 \\
$\begin{array}{l}\text { Arts } \\
\text { Any other }\end{array}$ & 6 & 6.00 & 6.00 & \\
$\quad$ Total & 100 & 6.00 & 6.00 & 100.00 \\
\hline
\end{tabular}

Table 5. Type of institutions

\begin{tabular}{lllcc}
\hline & Frequency & percent & $\begin{array}{c}\text { Valid } \\
\text { Percent }\end{array}$ & $\begin{array}{l}\text { Cumulative } \\
\text { Percent }\end{array}$ \\
\hline $\begin{array}{l}\text { Self Financed } \\
\begin{array}{l}\text { Government } \\
\text { financed }\end{array}\end{array}$ & 34 & 34.00 & 34.00 & 34.00 \\
$\begin{array}{l}\text { Any other } \\
\text { Total }\end{array}$ & 52 & 52.00 & 52.00 & 86.00 \\
\hline
\end{tabular}

Table 6. Reliability of the questionnaire used

\begin{tabular}{lcccc}
\hline Dimensions & $\begin{array}{c}\text { "Cronbach's } \\
\text { alpha" }\end{array}$ & $\begin{array}{l}\text { "Rho_ } \\
\mathbf{A} "\end{array}$ & $\begin{array}{l}\text { "Com } \\
\text { posite } \\
\text { reliabil } \\
\text { ity" }\end{array}$ & $\begin{array}{c}\text { "Average } \\
\text { Variance } \\
\text { extracted(AVE)" }\end{array}$ \\
\hline Cognitive Dimension & 0.904 & 0.908 & 0.924 & 0.636 \\
Regulative Dimension & 0.894 & 0.907 & 0.919 & 0.655 \\
Normative Dimension & 0.868 & 0.885 & 0.904 & 0.655 \\
\hline
\end{tabular}

Table 6 Represents the "Cronbach's alpha" along with "Rho_A" and composite reliability of cognitive dimension, Regulative dimension, and Normative dimension undertaken in the study. Cronbach's alpha ranges between 0.868 and 0.904 along with composite ranging from "0.904" to "0.924". According to (Claes Fornell and David F. Larcke,1981) Cronbach's above 0.6 and composite reliability above 0.7 is considered acceptable. Hence the questionnaire used in the study is consistent and items present in the questionnaire are closely related to each other.

"Rho_A" measures the internal consistency of the scale formulated and a value above 0.7 is considered acceptable. For the model formulated in this paper "Rho_A" values for all three variables, 
namely cognitive dimensions, Regulative dimension, and normative dimension are between 0.885 and 0.908 , so they are acceptable.

Hence the questionnaire used is reliable and consistent that can be used for evaluating the entrepreneurial profile of different states in India and for establishing the relationship between the three dimensions of institutional environment required for entrepreneurship development in India.

\section{Results and discussions}

\subsection{Proposed model}

On the basis of data collected from postgraduate students following model is formulated by doing factor analysis. This model depicts the relationship between three variables used in the study namely

"Normative dimensions", "Cognitive dimension" and "Regulative dimensions".

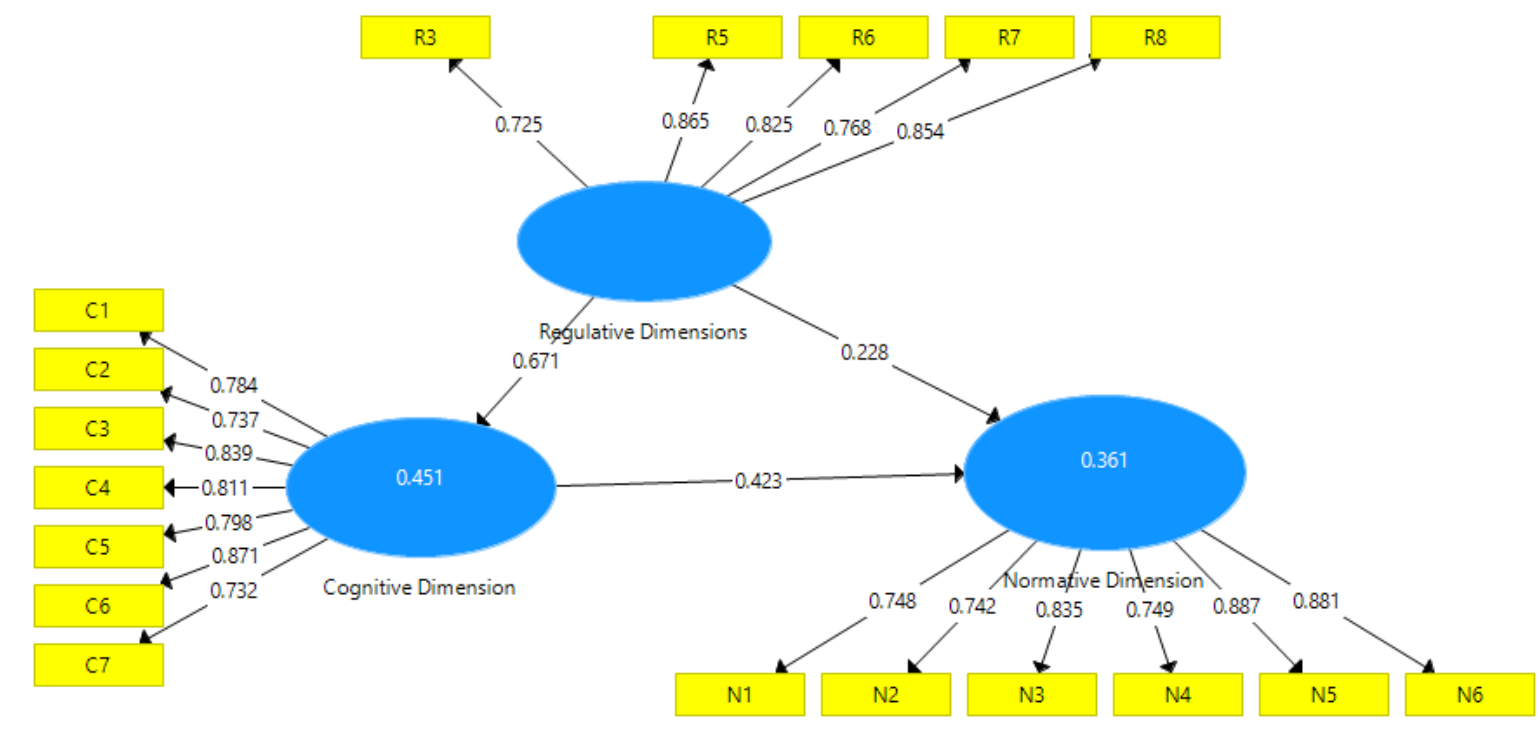

Figure 2. Proposed model analysis

A validity test is used to check the proposed model's fitness as it helps measure the concept of the proposed model formulated. Validity is further classified as "convergent validity" and "discriminant validity."

Convergent validity comprises "composite reliability" and "Average variance extracted" (AVE). As given in "Table 6" "the composite reliability" of all constructs is between 0.904 to 0.924 , which is well above the reasonable limit of 0.7 (Hair Jr, William C, Barry J., \& Rolph E., 2017). Apart from this AVE value calculated for all three constructs are above 0.5 and the AVE value above 0.5 is acceptable according to (J Hair Jr, Sarstedt, \& Hopkins, 2014). Hence the model formulated is valid.

\subsection{Evaluation of proposed model}

\subsubsection{Discriminate validity}

It can be defined as the extent by which construct of the model differs from each other. In this paper, we have used the VIF value to check this difference between the constructs. VIF indicates the high level of collinearity or multicollinearity between the independent constructs of the model. The threshold value for VIF for factor-based PLS algorithm is below or equal to 5 (Hair, Ringle, \& 
Sarstedt, 2011). The VIF value in the proposed model ranges from 1.59 to 3.92 all well below the limit 5 so the model proposed is free from collinearity and multicollinearity problems.

Table 7. VIF Value

\begin{tabular}{ll}
\hline Constructs & VIF \\
\hline C1 & 2.11 \\
C2 & 2.45 \\
C3 & 3.85 \\
C4 & 2.38 \\
C5 & 2.67 \\
C6 & 3.67 \\
C7 & 2.07 \\
N1 & 2.01 \\
N2 & 2.01 \\
N3 & 2.65 \\
\hline N5 & 2.00 \\
\hline N6 & 3.92 \\
R3 & 3.55 \\
R5 & 1.59 \\
R6 & 2.46 \\
\hline R7 & 2.04 \\
R8 & 1.82 \\
\hline
\end{tabular}

For checking the discriminant validity of HTMT values, the Fronell Larker method and cross-loading between the construct can be used. Among these three techniques, HTMT predicts the discriminant validity more precisely than the other two (Henseler, Ringle, \& Sarstedt, 2014). In this paper, we have used the HTMT technique, Fornell Larker Criterion, and cross-loading techniques to check the discriminant validity between the three constructs undertaken for the study.

\section{(a). HTMT values}

Value below .85 is acceptable as a threshold rule for HTMT (Ab Hamid, Sami, \& Mohmad Sidek, 2017). Values for three constructs, cognitive, normative, and regulative dimension of entrepreneurial environment, given in the table $\mathbf{8}$ are well below the acceptable limit of 0.85 , so the proposed model is free from the problem of discriminant validity.

Table 8. HTMT values

\begin{tabular}{|c|c|c|c|}
\hline Constructs & $\begin{array}{c}\text { "Cognitive } \\
\text { Dimension" }\end{array}$ & $\begin{array}{l}\text { "Normativ } \\
\text { e Dimension" }\end{array}$ & $\begin{array}{r}\text { "Regulativ } \\
\text { e Dimensions" }\end{array}$ \\
\hline "Cognitive Dimension" & & & \\
\hline "Normative Dimension" & 0.625 & & \\
\hline "Regulative Dimensions" & 0.746 & 0.566 & \\
\hline
\end{tabular}

\section{(b). Fornell-Larcker Criterion}

It is used to evaluate the discriminant validity of the constructs undertaken in the study. The thumb rule to check the discriminant validity by using the "Fornell Larcker Criterion" is that the value of the first construct should be greater than the values of the other constructs (Somjai, Chandarasorn, \& 
Vasuvanich, 2019). The value of the first construct given in table 9 is greater than the other construct. So the given model is free from the problem of discriminant validity.

Table 9. Fornell-Larcker criterion

\begin{tabular}{lccc}
\hline Dimensions & $\begin{array}{c}\text { "Cognitive } \\
\text { Dimension" }\end{array}$ & $\begin{array}{c}\text { "Normative } \\
\text { Dimension" }\end{array}$ & $\begin{array}{c}\text { "Regulative } \\
\text { Dimension" }\end{array}$ \\
\hline "Cognitive Dimension" & $\mathbf{0 . 7 9 8}$ & & \\
"Normative Dimension" & 0.576 & $\mathbf{0 . 8 0 9}$ & $\mathbf{0 . 8 0 9}$ \\
\hline "Regulative Dimension" & 0.671 & 0.512 & \\
\hline
\end{tabular}

\section{(c). Cross loading}

Variable or construct having more than one significant loading is termed as cross-loading( et al., 2017). "Acceptable discriminant validity would typically be assumed if the number in the diagonal cell for each column is greater than any of the other numbers in the same column" (Kock, 2015). In "table 10", it is clear that numbers or values in the diagonal cell for each column are greater than any of the other numbers or values in the respective column. Hence the proposed model is free from the problem of Discriminant Validity.

Table 10. Cross loading

\begin{tabular}{|cccc}
\hline & "Cognitive Dimension" & "Normative Dimension" & "Regulative Dimension" \\
\hline C1 & $\mathbf{0 . 7 8 4}$ & 0.329 & 0.482 \\
C2 & $\mathbf{0 . 7 3 7}$ & 0.491 & 0.510 \\
C3 & $\mathbf{0 . 8 3 9}$ & 0.587 & 0.517 \\
C4 & $\mathbf{0 . 8 1 1}$ & 0.526 & 0.545 \\
C5 & $\mathbf{0 . 7 9 8}$ & 0.353 & 0.523 \\
C6 & $\mathbf{0 . 8 7 1}$ & 0.469 & 0.585 \\
C7 & $\mathbf{0 . 7 3 2}$ & 0.412 & 0.576 \\
N1 & 0.439 & $\mathbf{0 . 7 4 8}$ & 0.400 \\
N2 & 0.374 & $\mathbf{0 . 7 4 2}$ & 0.363 \\
N3 & 0.458 & $\mathbf{0 . 8 3 5}$ & 0.405 \\
N4 & 0.397 & $\mathbf{0 . 7 4 9}$ & 0.339 \\
N5 & 0.535 & $\mathbf{0 . 8 8 7}$ & 0.476 \\
N6 & 0.561 & $\mathbf{0 . 8 8 1}$ & 0.480 \\
R3 & 0.413 & 0.346 & $\mathbf{0 . 7 2 5}$ \\
R5 & 0.581 & 0.491 & $\mathbf{0 . 8 6 5}$ \\
R6 & 0.604 & 0.404 & $\mathbf{0 . 8 2 5}$ \\
R7 & 0.462 & 0.298 & $\mathbf{0 . 7 6 8}$ \\
R8 & 0.614 & 0.492 & $\mathbf{0 . 8 5 4}$ \\
\hline
\end{tabular}

\subsubsection{Path coefficient}

Path coefficient is used to link the constructs in the structural model. Path coefficient values near 1 show a clear positive link between the constructs. It can be seen in the table $\mathbf{1 1}$ that the values are 0.67, 0.42, and 0.23 for the proposed constructs in respect to other constructs, respectively. Hence, three variables, namely Cognitive Dimension, normative dimension, and regression, have a relationship. This relationship can be further tested by running bootstrap. 
Table 11. Path coefficient

\begin{tabular}{lccc}
\hline & Cognitive Dimensions & Normative Dimensions & Regulative Dimensions \\
\hline Cognitive Dimensions & & 0.42 & \\
$\begin{array}{l}\text { Normative } \\
\text { Dimensions }\end{array}$ & & \\
$\begin{array}{l}\text { Regulative } \\
\text { Dimensions }\end{array}$ & 0.67 & 0.23 \\
\hline
\end{tabular}

\subsection{3. $R$ Square}

It tends to explain the endogenous variables with exogenous variables. The coefficient of determination "R square" varies between 0 to 1 higher the value better is the predicting accuracy. (Chin, 1998) described "values of "0.67", "0.33", and "0.19" as substantial, moderate, and weak". In our study, the values of $\mathrm{R}$ square found are "0.45" and "0.36", representing the moderate value according to chin 1988 hence predicting the relationship between the variables taken in the study.

Table 12. R Square

\begin{tabular}{lcc}
\hline Variables & "R square" & "R Square Adjusted" \\
\hline "Cognitive Dimensions" & $\mathbf{0 . 4 5}$ & $\mathbf{0 . 4 5}$ \\
"Normative Dimensions" & $\mathbf{0 . 3 6}$ & $\mathbf{0 . 3 5}$ \\
\hline
\end{tabular}

\subsubsection{F square value}

The f-square statistic is used to determine how significant the relation was between unobserved exogenous variables and indigenous unobserved variables. The small, medium and high effects of exogenous variables are described by "0.02", "0.15", and "0.35", respectively. (Cohen, 1992). As given in "table 13", the effects of variables are above .02, confirming that variables have moderate or high effects.

Table 13. F Square Value

\begin{tabular}{lccc}
\hline & $\begin{array}{c}\text { "Cognitive } \\
\text { Dimension" }\end{array}$ & $\begin{array}{c}\text { "Normative } \\
\text { Dimension" }\end{array}$ & $\begin{array}{c}\text { "Regulative } \\
\text { Dimension" }\end{array}$ \\
\hline "Cognitive Dimension" & & $\mathbf{0 . 1 5}$ & \\
"Normative Dimension" & & & \\
"Regulative Dimension" & $\mathbf{0 . 8 2}$ & $\mathbf{0 . 0 4}$ & \\
\hline
\end{tabular}

\subsection{5. $Q^{2}$ predictive relevance}

Apart from using " $\mathbf{R}^{2 "}$ for predicting model relevance, we have used a sample reuse technique by following the blindfolding procedure. " $\mathrm{Q}^{2}$ represents a measure of how the model and its parameters estimates reconstruct well-observed values. $\mathrm{Q}^{2}>0$ Implies the model has predictive relevance, whereas $\mathrm{Q}^{2}<0$ represents a lack of predictive" (Chin, 1998). The proposed model Value of $\mathrm{Q}^{2}$ for cognitive and normative dimensions are "0.27" and "0.21" which is well above 0 , so the proposed model has predictive relevance.

Table 14. $\mathrm{Q}^{2}$ predictive relevance

\begin{tabular}{llll}
\hline Variables & SSO & SSE & $\mathbf{Q}^{\mathbf{2}}=(\mathbf{1 - S S E} / \mathbf{S S O})$ \\
\hline Cognitive Dimension & 700.00 & 508.42 & 0.27 \\
Normative Dimension & 600.00 & 471.27 & 0.21 \\
Regulative Dimension & 500.00 & 500.00 & \\
\hline
\end{tabular}

\subsection{Model 2}

This model is obtained by running a bootstrap test on a given set of data in SmartPLS 3. It is a technique for obtaining a significant number of subsamples from a given sample with replacement to figure out the regular bootstrap standard errors that aid in calculating "T values" required for testing 
the significance of the structural path. T-Values help in the calculations of P values. (Belkhiri et al., 2015). Hypothesis can be tested by calculating the $\mathrm{P}$ values of the path coefficient.

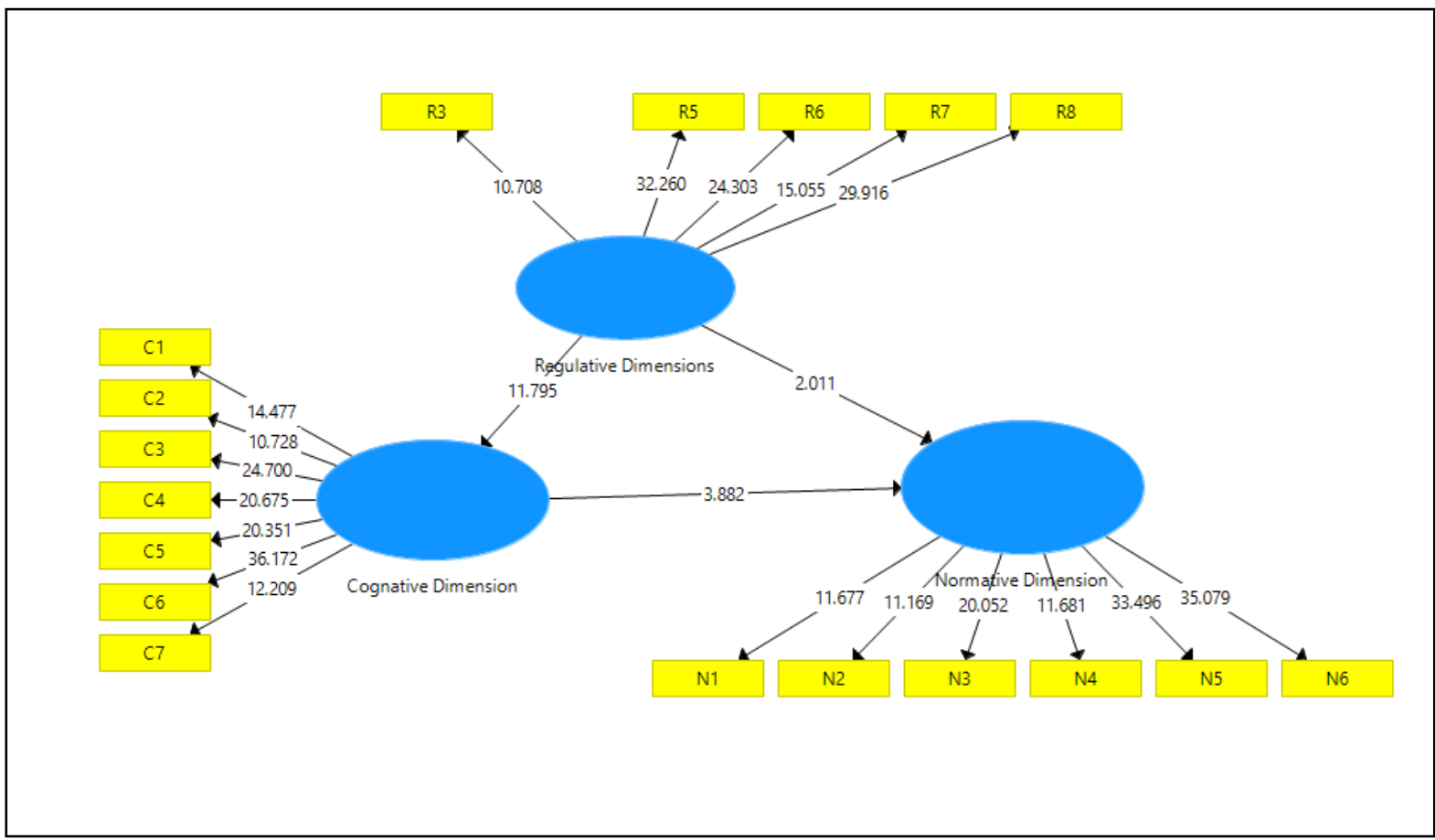

Figure 3. Model 2

This model tends to construct the relationship between the three constructs undertaken in the study in Indian conditions. This model explains how the "regulative dimension", "cognitive dimension" and "normative dimension" have a relationship with each other.

\subsection{Hypotheses testing}

Hypothesis 1 (H1) As depicted in table $15(\mathrm{O}=0.671 ; \mathrm{T}=11.795$ and $\mathrm{P}=0.00) \quad$ P-value is "0" that is below "0.05" so the proposed hypothesis $\mathbf{H 1}$ holds and it proves that the "regulative dimension" of institutional environment responsible for entrepreneurship development among the postgraduate has a significant positive relationship with the "cognitive dimension" of institutions responsible for entrepreneurship development in India.

Hypothesis 2 (H2) in Table 15 shows $(\mathrm{O}=0.423 ; \mathrm{T}=3.882$; and $\mathrm{P}=0.00)$ as $\mathbf{P}$-value is "0" that is below "0.05" that makes the proposed hypothesis $\mathbf{H} \mathbf{2}$ true, proving the significant positive relationship between "Cognitive and normative dimensions" of institutions responsible for entrepreneurship development among postgraduate students in India.

Hypothesis 3 (H3) As depicted in the table $15(0=0.228$; $\mathrm{T}=2.011$ and $\mathrm{P}=0.044) \mathbf{P}$-value is "0.044" that is less than "0.05" that makes the proposed hypothesis $\mathbf{H 3}$ accurate and proves that there exist a significant positive relationship between the "Regulative dimension" of institutions required for entrepreneurship development and "Normative dimensions" of the institutional environment required for entrepreneurship development in India. 
Table 15. Hypotheses testing results

$\begin{array}{lcccl}\text { Original } & \text { Sample Mean } & \text { Standard } & \text { T Statistics } & \text { P } \\ \text { Sample (O) } & (\mathrm{M}) & \begin{array}{c}\text { Deviation } \\ (\text { STDEV) }\end{array} & (\mid \text { O/STDEV|) } & \text { Values } \\ & & & & \end{array}$

\begin{tabular}{|c|c|c|c|c|c|}
\hline $\begin{array}{l}\text { Cognitive Dimension - } \\
\text { > Normative } \\
\text { Dimension }\end{array}$ & 0.423 & 0.426 & 0.109 & 3.882 & 0.000 \\
\hline $\begin{array}{l}\text { Regulative } \\
\text { Dimensions -> } \\
\text { Cognitive Dimension }\end{array}$ & 0.671 & 0.677 & 0.057 & 11.795 & 0.000 \\
\hline $\begin{array}{l}\text { Regulative } \\
\text { Dimensions -> } \\
\text { Normative Dimension }\end{array}$ & 0.228 & 0.233 & 0.114 & 2.011 & 0.044 \\
\hline
\end{tabular}

\section{Conclusion}

The results found in the study show that there exists a significant relationship between the "cognitive dimension, regulative dimension, and normative dimension" of institutions required for entrepreneurship development among the postgraduate students in India. As it can be seen, there exists a relationship between the "regulative dimension" and "normative dimension" of institutions required for entrepreneurship development among the postgraduates in India. Apart from this "regulative dimension" also shows a significant relationship with the "cognitive dimension" of institutions required for entrepreneurship development among the postgraduate students in India. The normative and cognitive dimension also shows a fair relationship between them as depicted in the structural model given in figure 3 .

\section{Limitation and study forward}

As the study was conducted on a small sample of 100 postgraduate students collected from two states of India, which decreases the reliability of the proposed model, due to which it may not show the same type of relationship among the three dimensions of institutes required for entrepreneurship development when conducted on a larger sample.

In the future, one can conduct the study on a bigger sample including all the states and union territories of India, which may increase the reliability and validity of the study and questionnaire developed in this study based on previous studies can be used to measure the entrepreneurial profile of different states in India.

\section{References}

Ab Hamid, M. R., Sami, W., \& Mohmad Sidek, M. H. (2017). Discriminant Validity Assessment: Use of Fornell \& Larcker criterion versus HTMT Criterion. Journal of Physics: Conference Series, 890(1), 6. https://doi.org/10.1088/1742-6596/890/1/012163

Acs, Z. (2006). How is Entrepreneurship Good for Economic Growth? Innovations: Technology, Governance, Globalization, 1(1), 97-107. Retrieved from https://www.mitpressjournals.org/doi/pdf/10.1162/itgg.2006.1.1.97

Adenutsi, D. E. (2009). Entrepreneurship, job creation, income empowerment and poverty reduction in low-income economies. MPRA Paper, (29569). Retrieved from http://ideas.repec.org/p/pra/mprapa/29569.html

Arasti, Z., Pasvishe, F. A., \& Motavaseli, M. (2012). Normative Institutional Factors Affecting Entrepreneurial Intention in Iranian Information Technology Sector. Journal of Management and Strategy, 3(2), 10. https://doi.org/10.5430/jms.v3n2p16

Baptista, R., Escária, V., \& Madruga, P. (2008). Entrepreneurship, regional development and job creation: The case of Portugal. Small Business Economics, 30(1), 49-58. 
https://doi.org/10.1007/s11187-007-9055-0

Baumol, W. J. (1990). Entrepreneurship : Productive , Unproductive , and Destructive. Journal of Political Economy, 98(5), 893-921. https://doi.org/141.218.001.105

Bednarzik, R. W. (2000). The role of entrepreneurship in U.S. and European job growth. Monthly Labor Review, 123(7), 3-16.

Belkhiri, L., Narany, T. S., Kock, N., Yana, A. A. G. A., Rusdhi, H. A., Wibowo, M. A., ... Simonović, S. P. (2015). Stable P value calculation methods in PLS-SEM. Water Resources Management, 29(August), 2073-2089. https://doi.org/10.13140/2.1.2215.3284

Brown, E. D. (2013). Three Essays on Entrepreneurship in India and the US: Policies, Social Ties and Mobility (Pardee rand graduates school). Retrieved from www.rand.org

Bruton, G. D., \& Ahlstrom, D. (2003). An institutional view of China's venture capital industry: Explaining the differences between China and the West. Journal of Business Venturing, 18(2), 233-259. https://doi.org/10.1016/S0883-9026(02)00079-4

Bruton, G. D., Ahlstrom, D., \& Li, H. L. (2010). Institutional theory and entrepreneurship: Where are we now and where do we need to move in the future? Entrepreneurship: Theory and Practice, 34(3), 421-440. https://doi.org/10.1111/j.1540-6520.2010.00390.x

Busenitz, L. W., Gómez, C., \& Spencer, J. W. (2000). Country institutional profiles: Unlocking entrepreneurial phenomena. Academy of Management Journal, 43(5), 994-1003. https://doi.org/10.2307/1556423

Carree, M. A., \& Thurik, A. R. (2010). The Impact of Entrepreneurship on Economic Growth. In Handbook of Entrepreneurship Research (pp. 557-594). https://doi.org/10.1007/978-1-44191191-9

Chin, W. W. (1998). The partial least squares approach for structural equation modeling. Modern Methods for Business Research, (January 1998), 295-336.

CLAES FORNELL AND DAVID F. LARCKE. (1981). Evaluating Stractural Equation Models with Unobservable Variables and Measurement. American Marketing Association, 18(1), 39-50. Retrieved from http://www.jstor.org/stable/3151312 .

Cohen, J. (1992). A power primer. Psychological Bulletin, 112(1), 155-159. https://doi.org/10.1037/0033-2909.112.1.155

Daneil Erian Armanies;Charles E.Eesley. (2021). How Do Institutional Carriers Alleviate Normative and Cognitive Barriers to Regulatory Change? Organization Science, 91. https://doi.org/https://doi.org/10.1287/orsc.2021.1434

Dickson, P. H., \& Weaver, K. M. (2008). The role of the institutional environment in determining firm orientations towards entrepreneurial behavior. International Entrepreneurship and Management Journal, 4, 467-483. https://doi.org/https://doi.org/10.1007/s11365-008-0088-x

Duygulu, E. (2008). Institutional profiles and entrepreneurship orientation: A case of Turkish graduate students. Munich Personal RePEc Archive, (7247), 1-18. Retrieved from http://mpra.ub.unimuenchen.de/7247/

Dwivedi, S. S. P. B. A. K. (2021). Global Entrepreneurship Monitor India Report 2019/20 A national study on Entrepreneurship. New York.

Eesley, C., Roberts, E. B., Tian, X., \& Yang, D. (2014). Institutional Flexibility and Entrepreneurship (No. 543). Retrieved from http://ssrn.com/abstract=1884493

El-Namaki, M. S. S. (1988). Encouraging entrepreneurs in developing countries. Long Range Planning, 21(4), 98-106. https://doi.org/10.1016/0024-6301(88)90014-3

Gupta, V. K., Guo, C., \& Canever, M. (2012). Institutional environment for entrepreneurship in rapidly emerging major economies : the case of Brazil, China, India, and Korea. International Entrepreneurship Management Journal, 10, 18. https://doi.org/10.1007/s11365-012-0221-8

Hair, J. F., Ringle, C. M., \& Sarstedt, M. (2011). PLS-SEM: Indeed a silver bullet. Journal of Marketing Theory and Practice, 19(2), 139-152. https://doi.org/10.2753/MTP10696679190202

Hair Jr, J. F., William C, B., Barry J., B., \& Rolph E., A. (2017). Multivariate Data Analysis (MVDA). In Pharmaceutical Quality by Design: A Practical Approach. https://doi.org/10.1002/9781118895238.ch8

Hayton, J. C., George, G., \& Zahra, S. A. (1979). National Culture and Entrepreneurship:Areview of 
Behaviooral Research. Group \& Organization Studies, 4(4), 509-512. https://doi.org/10.1177/105960117900400419

Henseler, J., Ringle, C. M., \& Sarstedt, M. (2014). A new criterion for assessing discriminant validity in variance-based structural equation modeling. Journal of the Academy of Marketing Science, 43(1), 115-135. https://doi.org/10.1007/s11747-014-0403-8

J.Strom, W. J. B. R. (2007). Moderator Comments Entrepreneurship and Economic Growth. Strategic Entrepreneurship Journal, 306(2007), 285-306. https://doi.org/10.1002/sej

Jeraj, Mitja; Marič, M. (2013). Entrepreneurial Curiosity - The New Construct. High Potentials, Lean Organiza- Tion, Internet of Things: Proceedings of the 32nd Inter National Conference on Organizational Science Devel- Opment, (1), 289-298. Retrieved from ttps://www.researchgate.net/publication/273137840\%0AEntrepreneurial

JHair Jr, J. F., Sarstedt, M., \& Hopkins, L. (2014). Partial least squares structural equation modeling (PLS-SEM) An emerging tool in business research. Practical Assessment, Research and Evaluation, 26(1), 1-16. https://doi.org/10.1108/ebr-10-2013-0128

Katz, J. A., \& Shepherd, D. A. (2003). COGNITIVE APPROACHES TO ENTREPRENEURSHIP RESEARCH. Advances in Entrepreneurship, Firm Emergence and Growth, Vol. 6, pp. 1-10. https://doi.org/10.1016/S1074-7540(03)06001-X

Kock, N. (2015). Common Method Bias in PLS-SEM: A full collinearity assessment approach. International Journal of E-Collaboration, 11(4), 1-10. https://doi.org/10.4018/ijec.2015100101

Lawrence, B. S., \& Tolbert, P. S. (2007). Organizational demography and individual careers: Structure, norms, and outcomes. In Handbook of Career Studies (pp. 399-421). https://doi.org/10.4135/9781412976107.n20

Lim, D. S. K., Hoon, C., \& Clercq, D. De. (2015). Engagement in entrepreneurship in emerging economies: Interactive effects of individual-level factors and institutional conditions. International Business Review, 13. https://doi.org/10.1016/j.ibusrev.2015.12.001

Manolova, T. S., Eunni, R. V, \& Gyoshev, B. S. (2008). Institutional environments for entrepreneurship: Evidence from emerging economies in Eastern Europe. Entrepreneurship: Theory and Practice, 32(1), 203-218. https://doi.org/10.1111/j.1540-6520.2007.00222.x

Minniti, M. (2008). The Role of Government Policy on Entrepreneurial Activity: Productive, Unproductive, or Destructive? Entrepreneurship Theory and Practice, (1), 176. https://doi.org/10.1111/j.1540-6520.2008.00255.x

Nafukho, F. M., \& Muyia, M. A. H. (2010). Entrepreneurship and socioeconomic development in Africa: A reality or myth? Journal of European Industrial Training, 34(2), 96-109. https://doi.org/10.1108/03090591011023961

Petrovskaya, I. A., Zaverskiy, S. M., \& Kiseleva, E. S. (2017). Attitude to entrepreneurship in Russia: Three-dimensional institutional approach. Advances in Systems Science and Applications, 17(2), 29-42. https://doi.org/10.25728/assa.2017.17.2.483

Reynolds, P. D. (2013). Who Starts New Firms? of Preliminary Explorations. 9(5), 449-462. https://doi.org/https://doi.org/10.1023/A:1007935726528

Sánchez, J. C., Carballo, T., \& Gutiérrez, A. (2011). The entrepreneur from a cognitive approach. Psicothema, 23(3), 433-438. Retrieved from http://www.ncbi.nlm.nih.gov/pubmed/21774897

Scott, W. R., Smith, K. G., \& Hitt, M. A. (2005). Institutional Theory : Contributing to a Theoretical Research Program. Great Minds in Management: The Process of Theory Development, (January 2005), 460-485. https://doi.org/0-19-927681-1. - 2005, p. 460-484

Sine, W. D., \& David, R. J. (2010). Institute and Entrepreneurship. Research in Sociology of Work, 21, 1-26. https://doi.org/10.1108/S0277-2833(2010)0000021005

Smith, D. (2010). The role of entrepreneurship in economic development. Undergraduate Eonomi Review, 6(1), 19. https://doi.org/10.4337/9781782540427.00010

Somjai, S., Chandarasorn, V., \& Vasuvanich, S. (2019). The impact of supply chain and supplier evaluation related practices on the performance of automotive industry in Thailand. International Journal of Supply Chain Management, 8(4), 455-466.

Spencer, J. W., \& Gómez, C. (2003). The relationship among national institutional structures, economic factors, and domestic entrepreneurial activity: A multicountry study. Journal of Business Research, 57(10), 1098-1107. https://doi.org/10.1016/S0148-2963(03)00040-7 
Stenholm, P., Acs, Z. J., \& Wuebker, R. (2013). Exploring Country-level Institutional Arrangements on the Rate and Type of Entrepreneurial Activity. Journal of Business Venturing, 28(1), 1-50. https://doi.org/https://doi.org/10.1016/j.jbusvent.2011.11.002

SusanBartholome. (1997). National Systems of Biotechbology Innovation:Complex Interdepencence in the Global System. Journal of International Business Studies,Second Quarter, (January), 241-266.

Turulja, L., Veselinovic, L., Agic, E., \& Pasic-Mesihovic, A. (2020). Entrepreneurial intention of students in Bosnia and Herzegovina: what type of support matters? Economic ResearchEkonomska Istrazivanja , 33(1), 2713-2732. https://doi.org/10.1080/1331677X.2020.1730216

Urban, B. (2013). Influence of the institutional environment on entrepreneurial intentions in an emerging economy. International Journal of Entrepreneurship and Innovation, 14(3), 179-191. https://doi.org/10.5367/ijei.2013.0122

Urban, B. (2019). The influence of the regulatory, normative and cognitive institutions on entrepreneurial orientation in South Africa. International Journal of Entrepreneurship and Innovation, 20(3), 182-193. https://doi.org/10.1177/1465750318796721

Urbano, D., \& Alvarez, C. (2013). Institutional dimensions and entrepreneurial activity: an international study. Small Business Economics, 42, 703-716. https://doi.org/https://doi.org/10.1007/s11187-013-9523-7

Valdez, M. E., \& Richardson, J. (2013). Institutional determinants of macro-level entrepreneurship. Entrepreneurship: Theory and Practice, 37(5), 1149-1175. https://doi.org/10.1111/etap.12000

Veciana, J. M., \& Urbano, D. (2008). The institutional approach to entrepreneurship research. Introduction. International Entrepreneurship and Management Journal, 4(4), 365-379. https://doi.org/10.1007/s11365-008-0081-4

W.Richard Scott. (1995). Institution and Organization. In Sage Publication (Vol. 1). https://doi.org/10.1017/S1352325200000288

Wannamakok, W., Chang, Y., \& Täks, M. (2020). The Relationship between Institutional Environments and Entrepreneurial Intention in Estonia: Mediating Roles of Desirability and Feasibility. Entrepreneurial Business and Economic Review, 8(2), 111-126.

Zhai, Q., \& Su, J. (2019). A perfect couple? Institutional theory and entrepreneurship research. Chinese Management Studies, 13(3), 616-644. https://doi.org/10.1108/CMS-07-2017-0194. 